\title{
Correspondence
}

\section{Pruritic secondary syphilis}

TO THE EDITOR, British Fournal of Venereal Diseases SIR-Generations of medical students have learned to respect syphilis as the 'great imitator,' capable of affecting all structures of the human body and mimicking a large number of disorders which comprise the disciplines of medicine and surgery. In spite of this recognition of the protean manner in which syphilis can present, several modern medical texts describe the cutaneous eruption of secondary syphilis as nonpruritic (Lomholt, 1972; Sutton and Waisman, 1975; Drusin, 1972; Allen, 1967; Pillsbury, Shelly and Kligman, 1956; USDHEW/PHS, 1968). Certain authors even advise that the absence of pruritis separates secondary syphilis from similar papulosquamous disorders which do itch (Olansky and Norins, 1971).

Recently, we diagnosed and treated three black patients with secondary syphilis who presented with intensely pruritic papular skin lesions (Cole, Amon, and Russell, in press). In all patients, a careful but unproductive search for lice and scabetic mites was made. Other pruritic dermatoses were excluded by historical data and appropriate laboratory tests. $2.4 \mathrm{~m}$.u. benzathine penicillin were administered intramuscularly to all patients with subsequent resolution of their pruritic skin lesions and a fall in previously elevated VDRL titres.

Sporadic references to pruritic papular (lichenoid and follicular) syphilids can be found in the medical literature (Lochner and Pomeranz, 1974; Stokes, Beerman, and Ingraham, 1944; Conant, 1974; King and Nicol, 1975). In those references, as in our cases, the majority of patients had pigmented skin.
The purpose of this communication is to warn practitioners that secondary syphilis can present as a pruritic dermatosis. This appears to be especially true in patients from darkly-pigmented races with papular syphilids.

ROBERT B. AMON, M.D. Gary W. Cole, M.D. Paul S. Russeli, M.D.

Department OF DeRMatology

University OF Oregon Health Sciences Center

PorTland, OREgoN 97201, U.S.A.

April 2, 1976

\section{References}

Allen, A. (1967) 'The Skin', 2nd ed., p. 451. Grune and Stratton, New York

Cole, G. W., Amon, R. B., and Russell, P. S. (In press) Arch. Dermat.

Conant, M. (1974) West. F. Med., 120, 41

Drusin, L. (1972) Med. Clin. N. Amer., 56, 1161

KING, A., and NiCOL, C. (1975) 'Venereal Diseases', 3rd ed., pp. 26-33. Bailliére Tindall, London

Lochner, J., and Pomeranz, J. (1974) Arch. Dermat., 109, 81

LOMHOLT, G. (1972) In 'Textbook of Dermatology', 2nd ed., ed. A. J. Rook and others, p. 645. Blackwell Scientific Publications, London

OLANSKY, S., and NoRINS, L. (1971) In 'Dermatology in General Medicine', 1st ed., ed. T. B. Fitzpatrick and others, p. 1961. McGraw Hill, New York

Pillsbury, D., SHELly, W., and Kirgman, A. (1956) 'Dermatology', 1st ed. p. 552. Saunders, Philadelphia

Stokes, J. H., BeERman, H., and Ingraham, N. R., Jr. (1944) 'Modern Clinical Syphilology', 3rd ed., p. 582. Saunders, Philadelphia

Sutron, R. L., Jr., and WAISMAN, M. (1975) 'The Practitioneer's Dermatology', 1st ed., p. 171. Dun-Donnelley, New York.

USDHEW/PHS (1968) 'Syphilis'. Public Health Service Publication No. 1660. U.S. Government Printing Office, Washington, D.C.

\section{Venereology or genito-urinary medicine}

\section{TO THE EDITOR, British fournal of Venereal Diseases} SIR-An editorial in the British Medical fournal ${ }^{1}$ advocated changing the name of venereology to genito-urinary medicine. Discussion and correspondence since show that there are two clearly opposed views on this matter.

Even the most distinguished expert may be wrong. The late Joseph Earle Moore of Johns Hopkins Hospital, the most eminent syphilologist of his era, was wrong when he proposed that venereologists in the United Kingdom, and syphilologists in the United States of America, should turn their attention to chronic diseases because of the 'conquest' of venereal disease by antibiotics. ${ }^{2} \mathrm{He}$ advocated that venereology should form a minor part of a wider clinical interest. This was a generally held view in the United States so that teaching of the subject in medical schools there virtually ceased, and the developing specialty of venereology disintegrated. Since then there has been an escalation of venereal disease in the United
States, so that serious attempts are being made there to revive and develop venereology. Distinguished experts were wrong there. We think that they are wrong here, in advocating the change of name from venereology, for the following reasons:

(1) Genito-urinary (or genital ${ }^{3}$ ) medicine is not a precise term; it does not define the work of venereology. The venereologist is concerned with the whole person exposed to disease, not just the genitalia or genitourinary tract. Moreover, there are many conditions of the genitalia and urinary tract that are outside the scope of venereology.

(2) In this country, the specialty dealing with sexuallytransmitted diseases has gained a clear identity of its own under the name of venereology. We think that this identity might be lost under any name that is not clearly definitive. Such a loss would, in the long run, 